\title{
Spectrophotometric Determination of Drugs and Pharmaceuticals by Cerium (IV) Amaranth Dye Couple
}

\author{
K.Sayanna ${ }^{1}$, G.Venkateshwarlu ${ }^{2}$ \\ ${ }^{a}$ Department of Chemistry, Nizam college/Osmania University, Hyderabad-500001,India \\ ${ }^{b}$ Department of Chemistry, Nizam college/Osmania University, Hyderabad-500001,India
}

\begin{abstract}
Simple, sensitive, accurate, and precise spectrophotometric methods for quantitative determination of drugs, viz., Darifenacin (DAR), Esmolol Hydrochloride (ESM), Montelukast Sodium (MON), Sildenafil citrate (SIL), Terbinafine (TER) and Tramadol Hydrochloride (TRA) were developed. The method of each drug depends upon oxidation of drugs by Ce (IV) (Excess) and estimating the amount of unreacted Ce (IV) by amaranth dye at 523nm. The calibration curves obeyed Beer's law over the concentration range of 1.4-7.0 $\mu \mathrm{g}$

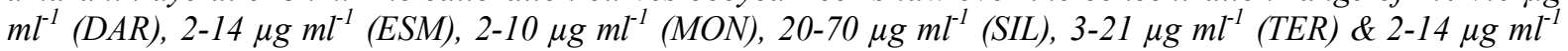
(TRA). The methods have been validated in terms of guidelines of ICH and applied to analysis of pharmaceuticals.
\end{abstract}

Keywords: Cerium (IV), Amaranth dye couple, drugs, Determination, UV-VIS Spectrohotometry

\section{Introduction}

\subsection{Darifenacin}

Darifenacin is chemically as (s)-2-\{1-[2-(2, 3-dihydrobenzofuran-5-yl) ethyl 3-pyrolidine $\}$ - 2diphenyl acetamide [Fig. 1(a)], is a $M_{3}$ receptor antagonist. It is used for treatment of overactive bladder with the symptoms of urinary frequency, urinary urgency, and urinary incontinence [1].

Because of its physiological significance several methods have been developed for its quantitative determination viz., PR-HPLC [2,3], HPTLC[4], Spectrophotometry [5,6] and Extractive spectrophotometry[7,8].

\subsection{Esmolol hydrochloride}

Esmolol hydrochloride (ESM), methyl 3-\{4-[2-hydroxy-3-(isopropylamino) propoxy] phenyl $\}$ propionate hydrochloride, is an ultra-short acting adrenergic receptor antagonist used for the rapid control of heart rate in patients with atrial fibrillation or atrial flutter. Since ESM is widely used in the rapid control of heart rate, it is important to develop and validate analytical methods for its determination in pharmaceutical dosage form. Review of literature has revealed that few methods have been reported for the estimation of Esmolol hydrochloride. Most HPLC methods reported are useful in estimating Esmolol hydrochloride in human plasma [9-13] and biological fluids [14]. HPLC [15, 16] methods have been reported for determination of ESM in pharmaceutical injections.

\subsection{Montelukast sodium}

Montelukast sodium 2-[1-[(R)-[3-[2(E)-(7-chloroquinolin-2- yl) vinyl] phenyl] -3-[2- (1-hydroxy-1methyl ethyl) phenyl] propyl - sulfanyl methyl] cyclo propyl] acetic acid sodium salt [Fig.1(c)]. It is an oral selective leukotriene receptor antagonist that inhibits the cysteinyl leukotriene cysLT1 and has been shown to be effective in the treatment of chronic asthma [17].

Several methods like Spectrophotometry for individual [18,19], combined dosage form [20], Highperformance liquid chromatography [21,22], Capillary electrophoresis [23] and Voltametric determination [24] have been developed.

\subsection{Sildenafil citrate}

Sildenafil citrate (SIL) is designated chemically as 1- h[3- (6,7-dihydro-1-methyl-7-oxo-3-propyl-1Hpyrazolo[4,3-d]pyrimidin-5-yl)-4-ethoxyphenyl]sulfonylj-4-methylpiperazine citrate and has the structural formula shown in [Fig. 1(d)]. It is used in oral therapy for erectile dysfunction, is a selective inhibitor of cyclic guanosine mono phosphate (cGMP) specific phosphodiesterase type 5 (PDE5) [25].

Some techniques have been developed for quantitative determination of SIL in pharmaceutical formulations. Some important ones are HPLC $[26,27,28]$, flow-injection analysis with multiple pulse amperometric detection [29], atomic emission spectrometry [30], spectrophotometry [31,32] and LC-MS [33 ].

\subsection{Terbinafine}

Terbinafine [Fig.1(e)], chemically (E)-N-(6,6-dimethyl-2-hepten-4-inyl)-N-Methyl-1-naphthalene 
methanamine, is an allyl amine derivative with antifungal activity. The drug has been found to be a potent inhibitor of squalene epoxidase which is an enzyme present in fungal and mammalian cell systems important in ergo sterol biosynthesis [34].

Because TER is widely used, several methods have been employed to determine TER in pharmaceutical formulations and they include Potentiometry [35], HPLC [36], RP-HPLC [37] and Spectrophotometry $[38,39]$.

\subsection{Tramadol hydrochloride}

Tramadol hydrochloride (TRA), chemically known as (1R, 2R) -rel-2- [(Dimethylamino) methyl]-1-(3methoxyphenyl)cyclohexanol; ( \pm )-cis-2 [Fig.1(f)], administrated orally non-steroidal anti-inflammatory drug which possesses good analgesic properties and good tolerability profile in variety of painful conditions [40].

Some methods Spetrophotometry [41, 42], HPLC [43], UV-Spectrometry [44], Potentiometry [45,46] and Conductometry [47] have been developed for the determination Tramadol $\mathrm{HCl}$.

Through survey of literature revealed that oxidative method of quantification of these drugs by Ce (IV) have been not reported yet, although the methods simple sensitive, precise and accurate [48, 49].

\section{About The Method}

Cerium (IV) is a good oxidizing agent like $\mathrm{KMnO}_{4}, \mathrm{~K}_{2} \mathrm{Cr}_{2} \mathrm{O}_{7}$ etc., it has been used for quantitative determination of drugs based on the oxidation of drugs. The spectrophotometric methods involved addition of excess $\mathrm{Ce}(\mathrm{IV})$ and un reacted cerium is estimated by suitable dyes, which should be oxidized by cerium viz., Indigo Carmine, Methyl Orange, Safranin-O and Xylene cyanol.

Amaranth dye is suitable for estimation of unreacted Ce (IV) absorbance at $523 \mathrm{~nm}$.

\subsection{Apparatus}

\section{Experimental}

Spectral and absorbance measurements were made on a thermo electron corporation single beam U.V.Vis spectrophotometer by using $1 \mathrm{~cm}$ quartz cells.

\subsection{Materials and methods} investigation.

All reagents used were of analytical-reagent grade and distilled water was used throughout the

\subsubsection{Cerium (iv) solution}

Cerium (IV) sulphate $\left(\mathrm{CeSO}_{4} \cdot 2 \mathrm{H}_{2} \mathrm{O}, 99.9 \%\right.$ pure) was prepared by dissolving $750 \mathrm{mg}$ of chemical (merck, mumbai, india) in $2 \mathrm{~N} \mathrm{H}_{2} \mathrm{SO}_{4}$ with the aid of heat and filtered using glass wool, and diluted to $250 \mathrm{ml}$ with the same acid and standardized and cerium is standardized by ferrous ammonium sulphate and ferroin indicator. The solution was then diluted appropriately with $2 \mathrm{~N} \mathrm{H}_{2} \mathrm{SO}_{4}$ to get working concentrations of 4.0x $10^{-3}$ $\mathrm{M}(0.25 \%)$.

\subsubsection{Amaranth dye}

Aqueous solutions of $0.8 \times 10^{-3} \mathrm{M}$ of Amaranth dye was prepared by dissolving an appropriate weight of 0.0483 grams in $100 \mathrm{ml}$ bi distilled water.

\subsubsection{Sulphuric acid}

Prepared by diluting the concentrated acid (Merck, Mumbai, India, Sp. gr. 1.84, $98.0 \%$ ) with water appropriately to get $2 \mathrm{~N}$ acid.

\subsubsection{Preparation of drug solution}

Standard drug solution $\left(200 \mu \mathrm{gml}^{-1}\right)$ was prepared by dissolving $20 \mathrm{mg}$ of drug with distilled water to the mark in $100 \mathrm{ml}$ standard flask. The stock solution was diluted appropriately to get the working concentration.

\section{Procedure}

Aliquots of studied drugs containing 1.4-70.00 $\mu \mathrm{g} / \mathrm{ml}$ of drug were transferred into a series of $10 \mathrm{ml}$ standard flasks using a micro burette. To each flask were added $1 \mathrm{ml}$ of sulfuric acid (2N) and $1 \mathrm{ml}$ of cerium (IV) ammonium sulfate solution $\left(250 \mu \mathrm{g} \mathrm{ml}^{-1}\right)$. The content mixed and heated on water at $60 \pm 2^{\circ} \mathrm{C}$ for $10 \mathrm{~min}$, then the solution was cooled for room temperature. Finally, $1 \mathrm{ml}$ of $0.02 \%$ of amaranth dye solution was added and diluted to the mark with doubly distilled water, mixed and absorbance of each solution measured at $523 \mathrm{~nm}$ 
against water blank.

\section{Assay Of Drug Pure Sample}

To the test the accuracy and precision of the methods developed pure sample solutions containing drug in the Beer's Law limit were chosen. For this study 1.4-7.0 $\mu \mathrm{gml}^{-1}$ of DAR, $10-70 \mu \mathrm{gml}^{-1}$ of ESM, 2-10 $\mu \mathrm{gml}^{-1}$ of MON, 20-70 $\mu \mathrm{gml}^{-1}$ of SIL, 3-21 $\mu \mathrm{gml}^{-1}$ of TER \& 2-14 $\mu \mathrm{gml}^{-1}$ of TRA have been taken. To each of the solution $1 \mathrm{ml}$ of $250 \mu \mathrm{g} \mathrm{ml}^{-1}$ of cerium $1 \mathrm{ml}$ of $2 \mathrm{~N}$ of $\mathrm{H}_{2} \mathrm{SO}_{4}$ were added the un reacted cerium is analyzed as described above using amaranth dye.

\subsection{Darifenacin}

\section{Procedure For Analysis Of Pharmaceuticals}

Four tablets (VESIGARD, 15mg tablet ${ }^{-1}$ ) were weighed and grounded. A quantity equivalent to $20 \mathrm{mg}$ of darifenacin was transferred into a $100 \mathrm{ml}$ calibrated flask and the volume was finally diluted to the mark with distilled water, mixed well and filtered using a whatmann No.42 filter paper. First $10 \mathrm{ml}$ portion of filtrate was discarded and a suitable aliquot of the subsequent portion was diluted appropriately to get required concentration and the assay was completed according to the procedure described above.

\subsection{Esmolol chloride}

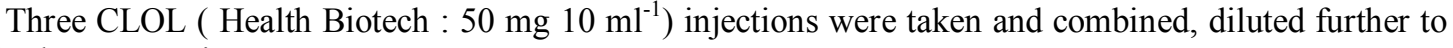
get required concentrations.

\subsection{Montelukast sodium}

Four tablet of MONTAIR (CIPLA : 10 $\mathrm{mg} \mathrm{tablet}^{-1}$ ) were accurately weighed and finely powdered. The powder equivalent to $20 \mathrm{mg}$ of MON was transferred into $100 \mathrm{ml}$ volumetric flask and dissolved in $0.2 \mathrm{M} \mathrm{H}_{2} \mathrm{SO}_{4}$ . then the solution was filtered using whatmann No:41 filter paper and further diluted with water to obtain working standard solution.

\subsection{Sildenafil citrate}

Four tablets of ALISIGA containing $25 \mathrm{mg}$ each amounting about $100 \mathrm{mg}$ of SIL was accurately weighed, dissolved in water and diluted to volume $100 \mathrm{ml}$ calibrated flask. This solution was diluted stepwise to give a series of concentrations suitable for the construction of the calibration graph.

\subsection{Terbinafine}

To determine the content of Terbinafine in pharmaceutical preparations, four tablets of Tebina (lable claim : $25 \mathrm{mg} / \mathrm{tablet}$ ) were weighed and finely powdered. A portion of the powder equivalent to $50 \mathrm{mg}$. Terbinafine was stirred with $50 \mathrm{ml}$ doubly distilled water and let stand for 10 minutes. The residue was filtered on Whatmann No.41 filter paper and wash with doubly distilled water. This solution was further diluted as necessary to complete the analysis concentration solutions for assay.

\subsection{Tramadol hydrochloride}

For the analysis of pharmaceutical formulations ten capsles (Dolotram: 20mg) were weigheted, powered and equivalent to $10 \mathrm{mg}$ of tramadol hydrochloride was transferred in to $100 \mathrm{ml}$ volumetric flask. 60.0 $\mathrm{ml}$ of distilled water was added and ultrasonicated for $20 \mathrm{~min}$, then made up to the mark with distilled water. The resulting solution was mixed and filtered through Whatmann filter paper no. 42. From the filtrate solution was diluted appropriately with distilled water in order to obtain working concentration of drug used for the analysis.

\section{Method Of Validation}

The each method developed quantification of drugs has been validated in terms of precision, accuracy, limit of detection, limit of quantification, linearity, selectivity and ruggedness. Absorbance time curves were drawn, initial rate and fixed time methods were used to assess the recovery of the drug. To assess the precision each experiment was repeated at least 5 times and accuracy is estimated in terms of percent recovery and percent RSD. Excellent percent recovery and RSD being less than 2 for each drug demonstrates accuracy and precision of the methods. Further t-test and F-test values have also been calculated using a standard reference method. The closeness of t-test and F-test values is less than that they permissible range indicating high accuracy of the methods [Table 2].

As mentioned earlier limit of detection is the minimum limit that can be detected but not necessarily quantified is determined for each drug.

LOD is determined from the standard deviation of y-intercepts of regression lines of replicate 
determinations.

$$
\begin{gathered}
\mathrm{LOD}=3.3 \mathrm{~s} / \mathrm{S} \\
\text { Where } \mathrm{s}=\text { standard deviation of intercept }(\mathrm{n}=6) \\
\mathrm{S}=\text { slope of linearity plot }
\end{gathered}
$$

LOQ the minimum concentration of analyst using calibration curve is also determined.

$$
\mathrm{LOQ}=10 \mathrm{~s} / \mathrm{S} \text {. }
$$

Limits of linearity of calibration curves are mentioned in the [Fig. 2] under the title Beer's law limit. To test the selectivity known excipients of each drug are added to the pure drug sample and recovery experiments were performed. Ruggedness is resistance of method for a small change in variables like instrument, and analyst or both to test the Ruggedness of the method absorbance data was collected using 3 different instrument and 2 analysts no significant changes were observed either by change of instrument or analyst hence the method may be taken as robust.

\section{1. Effect of acid concentration}

\section{Factors Effecting Absorbance}

To study the effect of acid concentration, different types of acids were examined $\left(\mathrm{H}_{2} \mathrm{SO}_{4}, \mathrm{H}_{3} \mathrm{PO}_{4}\right.$ and $\mathrm{CH}_{3} \mathrm{COOH}$ ) to achieve maximum yield of Redox reaction. The results indicated that the sulphuric acid was the preferable acid with Ce (IV) as oxidant. The reaction was performed in a series of $10 \mathrm{ml}$ volumetric flask containing $8.0 \mu \mathrm{gml}^{-1}$ of the cited drugs, different volumes $(0.5-2.5 \mathrm{ml})$ of $2.0 \mathrm{~N} \mathrm{H}_{2} \mathrm{SO}_{4}$ and $1 \mathrm{ml}$ of $\mathrm{Ce}(\mathrm{IV})$ $\left(4.0 \times 10^{-3} M\right)$ were added. After $5.0 \mathrm{~min}$ of heating time at $60 \pm 2^{\circ} \mathrm{C}$ in a water bath, the solution was cooled for about $3.0 \mathrm{~min}, 1.0 \mathrm{ml}$ of amaranth dye were added, then complete to $10 \mathrm{ml}$ total volume with water. It was found that the maximum absorbance was obtained at $1 \mathrm{ml}$ of $2 \mathrm{~N} \mathrm{H}_{2} \mathrm{SO}_{4}$. Above this volume, the absorbance decreased therefore, a volume of $1 \mathrm{ml}$ of $2 \mathrm{~N} \mathrm{H}_{2} \mathrm{SO}_{4}$ was used for all measurements.

\subsection{Effect of heating time}

In order to obtain the highest and most stable absorbance, the effect of heating time on the oxidation reaction of drugs were catalyzed by heating in a water bath at $60 \pm 2^{\circ} \mathrm{C}$ for the periods ranging for $2.5-20 \mathrm{~min}$. the time required to complete the reaction and maximum absorbance was obtained after $5.0 \mathrm{~min}$ of heating. After oxidation process, the solution must be cooled at least for $3.0 \mathrm{~min}$ before addition of dye.

\subsection{Effect of oxidant concentration}

When a study on the effect of Ce (IV) on color development was performed, it was observed that in both cases the absorbance increased with increase in the volume of Ce (IV). It reached maximum when $1 \mathrm{ml}$ of $200 \mu \mathrm{g} \mathrm{ml}^{-1} \mathrm{Ce}(\mathrm{IV})$ solution was added to a total volume of $10 \mathrm{ml}$ for drugs solutions. The color intensity decreased above the upper limits. Therefore, $1 \mathrm{ml}$ of $200 \mu \mathrm{g} \mathrm{ml}^{-1} \mathrm{Ce}$ (IV) was used for all measurements.

\subsection{Effect of dye concentration}

In order to ascertain the linear relationship between the volume of added Ce (IV) and the decrease in absorbance of Amaranth dye, experiments were performed using $1 \mathrm{ml}$ of $2 \mathrm{~N} \mathrm{H}_{2} \mathrm{SO}_{4}$ with varying volumes of Ce (IV). The decrease in absorbance was found to be linear up to the $1 \mathrm{ml}$ of $200 \mu \mathrm{g} \mathrm{ml}^{-1} \mathrm{Ce}$ (IV) with optimum volume $1.0 \mathrm{ml}$ of Amaranth dye for fixed concentration drug solution. The color was found to be stable up to 24 hours.

\section{Analysis Of Pharmaceuticals}

To the test the applicability of the method developed solution of pharmaceutical tablets solutions containing drug in the Beer's Law limit were chosen. To assess the precision each tablet analysis was repeated at least 6 times and accuracy is estimated in terms of percent recovery and percent RSD. Excellent percent recovery and RSD being less than 2 for each drug demonstrates applicability of the methods for pharmaceutical analysis [Table 3]. Further t-test and F-test values have also been calculated using a standard reference method. The closeness of t-test and F-test values is less than that they permissible range indicating excellent applicability of the methods for pharmaceutical analysis [Table 4]. The excellent recovery studies indicate that methods developed can be applied to pharmaceutical analysis without hesitation.

\section{Results And Discussion}

The ability of cerium (IV) sulphate to oxidize drugs, and bleach the color of amaranth dye is the basis of the indirect spectrophotometric method developed here. In this method the drugs were reacted with a measured excess of cerium(IV) sulphate in acidic medium and the unreacted oxidant was determined by reacting with amaranth followed by absorbance measurement at $523 \mathrm{~nm}$ ( scheme 1). The absorbance increased linearly with increasing concentration of drug, when increasing amounts of each drug were added to a fixed 
amount of $0.25 \%$ of CAS, consumed the latter and there occurred a concomitant fall in its concentration. When fixed amount of the dye was added to decreasing amount of oxidant, an concomitant increase in the concentration of dye resulted. This was observed as a proportional increase in absorbance at the respective $\lambda_{\max }$ with increasing concentration of each drug. One $\mathrm{ml}$ of $2 \mathrm{~N}$ acid was used in the reaction, as this concentration was found ideal.

$$
\begin{aligned}
& \mathrm{D}+\mathrm{Ce}(\mathrm{IV})_{\text {excess }} \rightarrow \mathrm{D} \text { oxidation product }+\mathrm{Ce}(\mathrm{III})+\mathrm{Ce}(\mathrm{IV})_{\text {unreacted }}: \text { (1) } \\
& \mathrm{Ce}(\mathrm{IV})_{\text {unreacted }}+\text { amaranth } \rightarrow \text { oxidation product of amaranth + uncreated amaranth : (2) } \\
& \text { Measured spectrophotometrically at } \lambda_{\max }=523 \mathrm{~nm}
\end{aligned}
$$

\section{Analytical Data}

A linear correlation was found between absorbance at $\lambda_{\max }$ and concentration ranges, and sensitivity parameters such as molar absorptivity, Sandal's sensitivity, detection limit and quantification limit are presented in Table 1. Regression analysis of Beer's law data using the method of least squares was made to evaluate the slope (b), intercept (a), correlation coefficient (r) and is also given in Table 1.

\section{Accuracy And Precision}

The accuracy and precision of the methods were established by analyzing the pure drug solution at 6 different levels (with working limits). The relative error (\%) which is a measure of accuracy \& RSD (\%) a measure of precision are summarized in Table 2 and reveal the high accuracy and precision of the methods.

\section{Conclusion}

The present study described the successful development of new, simple, sensitive, selective, accurate and rapid spectrohotometric method for the accurate determination of drugs each one in its pharmaceutical forms Cerium (IV) sulphate as the oxidizing reagent. There is no interference from additives and excipients. The method thus can be used in the determination of these drugs in pure and pharmaceutical formulations. So, it is the good alternative to the reported methods for the determination of these drugs.

\section{Acknowledgement}

We are grateful to Head, Department of Chemistry and Principal, Nizam College, Osmania University for providing facilities.

\section{References}

[1] The Merck Index, 13th edition, Merck Research laboratories, White House station, NJ, 2001, Pg: 495.

[2] Murthy, M. Vishnu; Krishnaiah, Ch.; Srinivas, K.; Rao, K. Srinivasa; Kumar, N. Ramesh; Mukkanti, K, Development and validation of RP-UPLC method for the determination of darifenacin hydrobromide, its related compounds and its degradation products using design of experiments, Journal of Pharmaceutical and Biomedical Analysis (2013), 72, 40-50.

[3] Panda, Sagar Suman; Kumar, B. V. V. Ravi; Patel, Pinkal Kumar; Mohanta, Ganeswar, New stability indicating RP-UFLC method for determination of darifenacin hydrobromide in extended release tablet dosage form, Journal of Pharmaceutical Education and Research (2012), 3(2), 7-12.

[4] Sathish, N. K.; Chethan, I. A.; Khandelwal, Pradeep V.; Shrestha, Ashwinee Kumar, Development and validation of rapid HPTLC method for determination of darifenacin hydrobromide in bulk drug and pharmaceutical dosage form, Chemica Sinica (2011), 2(3), $57-62$.

[5] Sathish, N. K.; Khandelwal, Pradeep V.; Chethan, I. A.; Shrestha, Ashwinee Kumar, UV spectrophotometric determination of darifenacin hydrobromide in bulk and pharmaceutical dosage forms, Pharmacia Sinica (2011), 2(2), 169-176

[6] Sai Praveen, P.; Shaiba, M.; Swetha, A.; Aruna Jyothi, A.; Nishat, Amreen, Spectrophotometric methods for the determination of Darifenacin, Research Journal of Pharmaceutical, Biological and Chemical Sciences (2010), 1(4), 350-353.

[7] Sai Praveen, P.; Jagathi, V.; Devala Rao, G.; Sudhakar Saibabu, G., Visible spectrophotometric methods for the determination of Darifenacin, Research Journal of Pharmaceutical, Biological and Chemical Sciences (2010), 1(2), 254-257.

[8] Praveen, P. Sai; Jagathi, V.; Rao, G. Devala; Saibabu, G. Sudhakar, Extractive spectrophotometric methods for the determination of Darifenacin, Oriental Journal of Chemistry (2010), 26(1), 195-197.

[9] Tang Y, He Y, Yao T and Zeng S. Simultaneous determination of the enantiomers of esmolol and its acid metabolite in humanplasma by reversed phase liquid chromatography with solidphase extraction, J Chromatogr B. 805; 2004: $249-254$.

[10] Tang Y, He Y, Yao T and Zeng S, Stereoselective RP-HPLC determination of esmolol enantiomers in human plasma after precolumn derivatization, J Biochem Biophys Methods. 59; 2004:159-166.

[11] Maurer H H, Tenberken O, Kratzsch C, Weber A A and Peters F.T., Screening for library-assisted identification and fully validatedquantification of 22 beta-blockers in blood plasma by liquid chromatography-mass spectrometry with atmospheric pressure chemical ionization J Chromatogr A. 1058; 2004: 169-181.

[12] Zuppa A F, Shi, Adamson H and Peter C., Liquid chromatography-electrospray mass spectrometry (LC-MS) method for determination of esmolol concentration in human plasma, J Chromatogr B. 796; 2003: 293-301...

[13] Achari R, Drissel D and Hulse J D, Liquid-chromatographic analysis for esmolol and its majormetabolite in urine, Clin Chem. 32; 1986: 374-376.

[14]] Malovaná S, Gajdošová D, Benedik J and Havel, J, Determination of esmolol in serum by capillary zone. electrophoresis and its monitoring in course of heart surgery, J Chromatogr B. 760; 2001: 37-43. 
[15] Vanita somasekhar and. D. Gowri sankar, Development and Validation of a Rapid RP-HPLC Method for the Estimation of Esmolol Hydrochloride in Bulk and Pharmaceutical Dosage Forms, E-Journal of Chemistry. 3; 2010: 807-812.

[16] Liu, Zhong; Xu, Jun; Zhang, Yi; Chen, Guanrong, Determination of esmolol hydrochloride and related substances by HPLC Zhongguo Yiyuan Yaoxue Zazhi (2006), 26(1), 104-106.

[17] Smita Sharmaa, M. C. Sharma*, D. V. Kohlib, A. D. Sharmac, Development and Validation of TLC-Densitometry Method for Simultaneous Quantification of Montelukast Sodium and Levocetirizine Dihydrochloride Pharmaceutical Solid dosage form Der, Pharmacia Lettre 2010: 2 (1) 489-494

[18] Shanmukha, Kumar J. V.; Geeta, Swarupa P.; Vardhan, S. V. M.; Ramachandran, D, Spectrophotometric determination of montelukast sodium in bulk and pharmaceutical formulations, Pharma Chemica (2012), 4(2), 720-724.

[19] Patel, Nilam K.; Pancholi, S. S., Spectrophotometric determination of montelukast sodium and levocetirizine dihydrochloride in tablet dosage form by AUC curve method, Pharma Chemica (2011), 3(5), 135-140

[20] Bankar, Rima M.; Patel, Dipti B., Spectrophotometric determination of Montelukast Sodium and Desloratadine in combined dosage form, International Journal of ChemTech Research (2013), 5(1), 136-141.

[21] Shi, Yun-feng; Lin, Li-qin, HPLC determination of montelukast sodium tablets and its related substances, Yaowu Fenxi Zazhi (2013), 33(2), 308-311.

[22] Naga Raju, K.; Gopala Swamy, T.; Lakshmana Rao, A., Development and validation of RP-HPLC method for the determination of montelukast sodium in bulk and in pharmaceutical formulation, International Journal of Pharmaceutical, Chemical and Biological Sciences (2011), 1(1), 12-16

[23] Shakalisava, Yuliya; Regan, Fiona, Determination of montelukast sodium by capillary electrophoresis, Journal of Separation Science (2008), 31(6-7), 1137-1143.

[24] Alsarra, I.; Al-Omar, M.; Gadkariem, E. A.; Belal, F., Voltammetric determination of montelukast sodium in dosage forms and human plasma, Farmaco (2005), 60(6-7), 563-567.

[25] J.J. Berzas Nevado, J. Rodr' 'guez Flores*, G. Castañeda Peñalvo, N. Rodr'́guez Fariñas, Determination of sildenafil citrate and its main metabolite by Sample stacking with polarity switching using micellar electrokinetic chromatography, Journal of Chromatography A, 953 (2002) 279-286

[26] Cao, Ling; Wu, Yan-yan; Zhang, Yu-lin; Lu, Yin-sheng, Evaluation of uncertainty for determination of sildenafil citrate added in health products by HPLC, Xiandai Shipin Keji (2012), 28(7), 890-893.

[27] Ghodsi, Razieh; Kobarfard, Farzad; Tabatabai, Sayyed Abbas, Application of narrow-bore HPLC columns in rapid determination of sildenafil citrate in its pharmaceutical dosage Forms, Iranian Journal of Pharmaceutical Research (2012), 11(1), 123-127.

[28] Zhong, Hua; Liang, Shu-ming; Zeng, Wei-jie; Gao, Kai-wen, Determination of sildenafil citrate in health foods by high performance liquid chromatography with solid phase extraction, Xiandai Shipin Keji (2010), 26(2), 206-208.

[29] Lopes, Antonio Carlos V., Jr.; Luz, Rita de Cassia Silva; Damos, Flavio S.; dos Santos, Alexandre S.; Franco, Diego L.; Pio dos Santos, Wallans T., Determination of sildenafil citrate (Viagra) in various pharmaceutical formulations by flow injection analysis with multiple pulse amperometric detection, Journal of the Brazilian Chemical Society (2012), 23(10), 1800-1806.

[30] Khalil, Sabry; El-Naggar, A. Y., Analytical utility of atomic emission spectrometry for the determination of sildenafil citrate (Viagra) in pharmaceutical formulations, Analytical Chemistry: An Indian Journal (2012), 11(2), 66-72.

[31] Frag, Eman Y. Z.; Mohamed, Gehad G.; Alelaiwi, Hana M. S. Utility of ion-associate formation reactions for the spectrophotometric determination of sildenafil citrate in pure form and in Virecta tablets, Pharmaceutica Analytica Acta (2011), 2(6), 131 .

[32] Thangabalan, B.; Vadivel, K.; Sowjanya, K.; Tejaswi, G.; Thejaroop, N.; Manohar babu, S.; Vijayaraj Kumar, P., Quantitative spectrophotometric determination of sildenafil citrate in tablet formulation using urea as hydrotropic solubilizing agent, Research Journal of Pharmaceutical, Biological and Chemical Sciences (2011), 2(2), 235-239

[33] Ren, Shuling; Zhu, Xujiang, Determination of sildenafil citrate-illegally mixed into Jinsuo Gujing pills by LC-MS, Zhongguo Xiandai Yingyong Yaoxue (2010), 27(4), 358-360..

[34] Suma, B. V.; Kannan, K.; Madhavan, V.; Nayar, Chandini R., HPTLC method for determination of Terbinafine in the bulk drug and tablet dosage form, International Journal of ChemTech Research (2011), 3(2), 742-748.

[35] Faridbod, Farnoush; Ganjali, Mohammad Reza; Norouzi, Parviz, Potentiometric PVC membrane sensor for the determination of Terbinafine, International Journal of Electrochemical Science (2013), 8(5), 6107-6117.

[36] Li, Yan-bo; Wang, Chao; Zhao, Xiao-dong; Lu, Jun; Chen, Xiao-hui, Determination of terbinafine hydrochloride content in functional cosmetics by high performance liquid chromatography, Riyong Huaxue Gongye (2012), 42(3), 234-236.

[37] He, Wenyue; Xu, Airen; Chen, Wu; Ma, Weicheng, Determination of terbinafine in human plasma by RP-HPLC, Zhongguo Yaoshi (Wuhan, China) (2012), 15(9), 1276-1278.

[38] Mrutyunjayarao, R.; Naresh, Saranapu; Pendem, Krishna; Rao, Psnh Ramachandra; Sasttry, C. S. P.; Viplava Prasad, U., Three Simple Spectrometric Determination of Terbinafine Hydrochloride (TRB) in Pure State and Tablets, Proceedings of the National Academy of Sciences, India, Section A: Physical Sciences (2012), 82(3), 221-224.

[39] Chennaiah, M.; Veeraiah, T.; Kumar, T. Vinod; Venkateshwarlu, G., Extractive spectrophotometric methods for determination of terbinafine hydrochloride in pharmaceutical formulations using some acidic triphenylmethane dyes, Indian Journal of Chemical Technology (2012), 19(3), 218-221

[40] Ramesh Sawant, Lokesh Bhangale, Rupali Joshi and Prashant Lanke, Validated spectrophotometric methods for simultaneous estimation of Paracetamol, Domperidone and Tramadol HCl in pure and tablet dosage form, J. Chem. Metrol. 4:1 (2010) 21-27

[41] Vinay, Kanakapura B.; Revenasiddappa, Hosakere D.; Abdulrahman, Sameer A. M., Sensitive spectrophotometric determination of tramadol hydrochloride in pharmaceuticals using Folin-Ciocalteu's reagent, Turkish Journal of Pharmaceutical Sciences (2013), 10(1), 57-68.

[42] Krishna, L. Mohan; Reddy, P. Jayachandra; Reddy, V. Jaya Sankar; Rao, K. V. S. Prasada, Spectrophotometric determination of tramadol hydrochloride using quinines, Journal of the Institution of Chemists (India) (2012), 84(4), 111-113.

[43] Qu Lingbo; Feng Shuhui; Wu Yongjun; Wu Yuming, HPLC method for determination of tramadol hydrochloride in human plasma Sichuan da xue xue bao. Yi xue ban = Journal of Sichuan University. Medical science edition (2003), 34(3), 574-5,

[44] Kucuk Aysel; Kadioglu Yucel, Determination of tramadol hydrochloride in ampoule dosage forms by using UV spectrophotometric and HPLC-DAD methods in methanol and water media, Farmaco (Societa chimica italiana : 1989) (2005), 60(2), 163-9

[45] Abu Shawish, Hazem M.; Al-Dalou, Ayoub R.; Abu Ghalwa, Nasser; Abou Assi, Anwar A., Potentiometric sensor for determination of tramadol hydrochloride in pharmaceutical preparations and biological fluids, Pharmaceutica Analytica Acta (2010), 1(1), 103

[46] Maha, El-Tohamy; Magda, El-Maamly; Waffa, S. Hassan; Shalaby, Abdalla, Direct potentiometric determination of tramadol hydrochloride in pharmaceutical preparations and biological fluids, Oriental Journal of Chemistry (2006), 22(3), 517-526 
[47] Huang, Chaolun; Dong, Qiuxiang; Ji, Guorong; Cai, Binxue; Wu, Haiyan, Determination of tramadol hydrochloride and its tablets by conductometric titration, Zhongguo Yiyao Gongye Zazhi (2006), 37(2), 115-117

[48] Sara Abdulgader Mohammed Ebraheem, Abdalla Ahmed Elbashir, Spectrophotometric method for the determination of ofloxacin and levofloxacin in pharmaceutical formulations, American Academic \& Scholarly Research Journal Vol. 4, No. 2, March 2012

[49] B Narayana \& K Ashwini, Spectrophotometric determination of frusemide by its oxidation with ceric ammonium sulphate, Indian journal of chemical technology vol.17, march-2010,pp 150-153

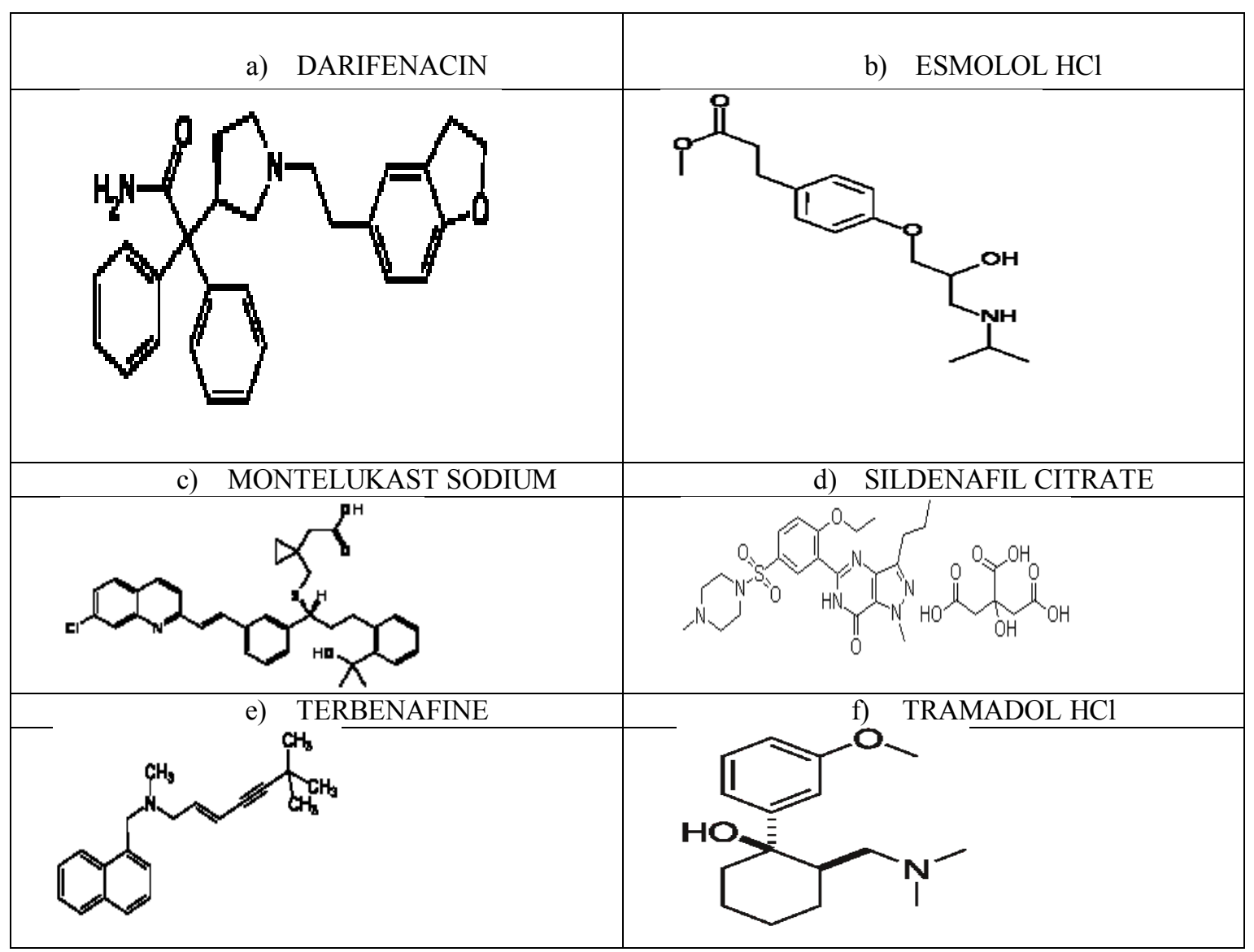

Fig.1: structures of drugs

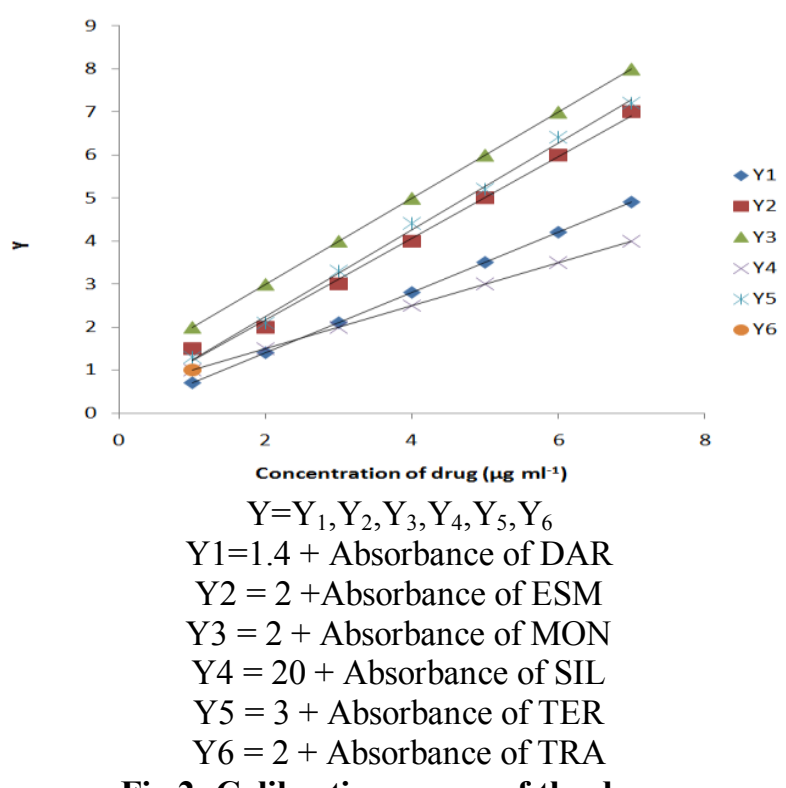

Fig.2: Calibration curves of the drugs 
Table 1: Analytical and regression parameters of Spectrophotometric method

\begin{tabular}{|c|c|c|c|c|c|c|}
\hline Parameter & DAR & ESM & MON & SIL & TER & TRAM \\
\hline $\begin{array}{c}\lambda \max \\
(\mathrm{nm})\end{array}$ & 523 & 523 & 523 & 523 & 523 & 523 \\
\hline $\begin{array}{l}\text { Beer's law limits } \\
\left(\mu \mathrm{g} \mathrm{ml}^{-1}\right)\end{array}$ & $0.7-7.0$ & $2-14$ & $1-7$ & $5-35$ & $3-21$ & $2-14$ \\
\hline $\begin{array}{c}\text { Molar absorptivity } \\
\left(\mathrm{L} \mathrm{mol}^{-1} \mathrm{~cm}^{-1}\right)\end{array}$ & $3.7 \times 10^{6}$ & $2.5 \times 10^{5}$ & $3.5 \times 10^{6}$ & $4.3 \times 10^{5}$ & $1.07 \times 10^{6}$ & $2.3 \times 10^{6}$ \\
\hline $\begin{array}{l}\text { Sandell sensitivity* } \\
\left(\mu \mathrm{g} \mathrm{cm}^{-2}\right)\end{array}$ & 0.0085 & 0.0018 & 0.1045 & 0.0926 & 0.0289 & 0.0085 \\
\hline $\begin{array}{l}\text { Limit of detection } \\
\left(\mu \mathrm{g} \mathrm{ml}^{-1}\right)\end{array}$ & 0.3517 & 0.1796 & 0.5862 & 2.6889 & 2.0637 & 0.3517 \\
\hline $\begin{array}{c}\text { Limit of } \\
\text { quantification } \\
\mu \mathrm{g} \mathrm{ml}^{-1}\end{array}$ & 1.0656 & 0.5450 & 1.7763 & 81.480 & 6.2536 & 1.0656 \\
\hline $\begin{array}{l}\text { Regression equation } \\
\left(\mathrm{Y}^{* *}=\mathrm{a}+\mathrm{bX}\right)\end{array}$ & 0.1808 & 0.0019 & 0.2324 & 0.2183 & 0.1199 & 0.1436 \\
\hline Intercept, (a) & 0.0166 & 0.0093 & 0.041 & 0.0023 & 0.0158 & 0.0166 \\
\hline Slope, (b) & 0.1173 & 0.5433 & 0.0957 & 0.0108 & 0.0347 & 0.1173 \\
\hline $\begin{array}{c}\text { Correlation } \\
\text { coefficient, }(\mathrm{r})\end{array}$ & 0.9872 & 0.9882 & 0.9947 & 0.994 & 0.994 & 0.987 \\
\hline $\begin{array}{l}\text { Standard deviation } \\
\text { of intercept }\left(\mathrm{S}_{\mathrm{a}}\right)\end{array}$ & 0.0125 & 0.0296 & 0.017 & 0.0088 & 0.0217 & 0.0125 \\
\hline $\begin{array}{l}\text { Standard deviation } \\
\text { of slope }\left(\mathrm{S}_{\mathrm{b}}\right)\end{array}$ & 0.0050 & 0.0296 & 0.0048 & 0.0008 & 0.0020 & 0.0047 \\
\hline
\end{tabular}

*Limit of determination as the weight in $\mu \mathrm{g}$ per $\mathrm{mL}$ of solution, which corresponds to an absorbance of $\mathrm{A}=0.001$ measured in a cuvette of cross-sectional area $1 \mathrm{~cm} 2$ and path length of $1 \mathrm{~cm} . \mathrm{Y}^{* *}=\mathrm{a}+\mathrm{bX}$, where $\mathrm{Y}$ is the absorbance and $\mathrm{X}=$ concentration of $\operatorname{drug}\left(\mu \mathrm{g} \mathrm{ml}^{-1}\right)$

Table 2: Determination of accuracy and precision of the methods on pure drug Samples

\begin{tabular}{|c|c|c|c|c|c|c|}
\hline Drug & 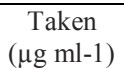 & $\begin{array}{c}\text { Found } \\
(\mu \mathrm{g} \mathrm{ml}-1)\end{array}$ & ER $(\%)$ & $\begin{array}{c}\text { Recovery } \\
(\%)\end{array}$ & $\operatorname{RSD}(\%)$ & $\begin{array}{c}\text { Proposed method } \\
\text { Mean } \pm \text { SD }\end{array}$ \\
\hline DAR & $\begin{array}{l}1.5 \\
2.5 \\
3.0 \\
4.5 \\
5.5\end{array}$ & $\begin{array}{c}1.49 \\
2.49 \\
3.01 \\
4.52 \\
5.5\end{array}$ & $\begin{array}{l}0.67 \\
0.40 \\
0.33 \\
0.44 \\
0.00\end{array}$ & $\begin{array}{c}99.33 \\
99.60 \\
100.30 \\
100.44 \\
100.00\end{array}$ & 0.4669 & $\begin{array}{c}99.92 \\
\pm 0.4651\end{array}$ \\
\hline ESM & $\begin{array}{c}3.0 \\
5.0 \\
7.0 \\
9.0 \\
11.0\end{array}$ & $\begin{array}{c}2.99 \\
5.01 \\
6.98 \\
9.01 \\
11.02\end{array}$ & $\begin{array}{l}0.33 \\
0.20 \\
0.29 \\
0.11 \\
0.18\end{array}$ & $\begin{array}{c}99.67 \\
100.2 \\
99.71 \\
100.11 \\
100.1\end{array}$ & 0.2482 & $\begin{array}{c}99.96 \\
\pm 0.251\end{array}$ \\
\hline $\mathrm{MON}$ & $\begin{array}{l}1.5 \\
2.5 \\
3.5 \\
4.5 \\
5.5\end{array}$ & $\begin{array}{l}1.49 \\
2.51 \\
3.48 \\
4.52 \\
5.49\end{array}$ & $\begin{array}{l}0.67 \\
0.40 \\
0.57 \\
0.44 \\
0.18\end{array}$ & $\begin{array}{c}99.33 \\
100.4 \\
99.43 \\
100.44 \\
99.82\end{array}$ & 0.5232 & $\begin{array}{c}99.90 \\
\pm 0.504\end{array}$ \\
\hline SIL & $\begin{array}{l}11.0 \\
15.0 \\
18.0 \\
22.0 \\
25.0\end{array}$ & $\begin{array}{l}11.02 \\
14.99 \\
18.01 \\
21.99 \\
24.47\end{array}$ & $\begin{array}{l}0.18 \\
0.22 \\
0.06 \\
0.45 \\
0.12\end{array}$ & $\begin{array}{c}100.18 \\
99.93 \\
100.05 \\
99.96 \\
97.88\end{array}$ & 0.9703 & $\begin{array}{c}99.80 \\
\pm 0.965\end{array}$ \\
\hline TER & $\begin{array}{c}4.0 \\
5.0 \\
7.0 \\
8.0 \\
10.0 \\
\end{array}$ & $\begin{array}{l}3.97 \\
4.98 \\
6.99 \\
7.98 \\
9.98 \\
\end{array}$ & $\begin{array}{l}0.75 \\
0.40 \\
0.14 \\
0.25 \\
0.20 \\
\end{array}$ & $\begin{array}{l}99.25 \\
99.60 \\
99.86 \\
99.75 \\
99.80\end{array}$ & 0.2454 & $\begin{array}{c}99.55 \\
\pm 0.239\end{array}$ \\
\hline TRA & $\begin{array}{c}3.0 \\
5.0 \\
7.0 \\
9.0 \\
11.0 \\
\end{array}$ & $\begin{array}{c}2.98 \\
4.99 \\
7.01 \\
8.98 \\
10.97\end{array}$ & $\begin{array}{l}0.67 \\
0.20 \\
0.14 \\
0.22 \\
0.27\end{array}$ & $\begin{array}{c}99.33 \\
99.80 \\
100.14 \\
99.78 \\
99.73\end{array}$ & 0.2889 & $\begin{array}{c}99.82 \\
\pm 0.302\end{array}$ \\
\hline
\end{tabular}


Table 3: Results of assay of tablets by the proposed methods and statistical evaluation and recovery experiments by standard addition method.

\begin{tabular}{|c|c|c|c|c|c|c|c|c|}
\hline $\begin{array}{l}\text { Pharmaceuticals/ } \\
\text { tablets/ } \\
\text { injection }\end{array}$ & $\begin{array}{l}\text { Drug in } \\
\text { tablet } \\
\left(\mu \mathrm{g} \mathrm{ml}^{-1}\right)\end{array}$ & $\begin{array}{c}\text { Drug } \\
\text { added } \\
\left(\mu \mathrm{g} \mathrm{ml}^{-1}\right)\end{array}$ & $\begin{array}{c}\text { Total } \\
\text { found } \\
(\mu \mathrm{g} \\
\left.\mathrm{ml}^{-1}\right)\end{array}$ & ER\% & $\begin{array}{c}\text { Recovery } \\
\%\end{array}$ & RSD $\%$ & $\begin{array}{l}\text { Reference } \\
\text { method } \\
\text { mean } \\
\pm \mathrm{SD}\end{array}$ & $\begin{array}{c}\text { Proposed } \\
\text { method } \\
\pm \mathrm{SD}\end{array}$ \\
\hline $\begin{array}{c}\text { DAR } \\
\text { (VESIGARD) }\end{array}$ & $\begin{array}{l}1.0 \\
2.0 \\
3.0 \\
4.0\end{array}$ & $\begin{array}{c}0.5 \\
1.0 \\
0.00 \\
0.00\end{array}$ & $\begin{array}{l}1.52 \\
2.98 \\
3.01 \\
3.99\end{array}$ & $\begin{array}{l}1.33 \\
0.67 \\
0.33 \\
0.25\end{array}$ & $\begin{array}{c}101.33 \\
99.33 \\
100.33 \\
99.75\end{array}$ & 0.864 & $\begin{array}{c}99.69 \\
\pm 0.909\end{array}$ & $\begin{array}{l}100.16 \\
\pm 0.863\end{array}$ \\
\hline $\begin{array}{c}\text { ESM } \\
(\mathrm{CLOL})\end{array}$ & $\begin{array}{l}1.0 \\
1.0 \\
2.0 \\
3.0\end{array}$ & $\begin{array}{l}0.5 \\
1.0 \\
1.0 \\
1.0\end{array}$ & $\begin{array}{l}1.49 \\
2.03 \\
3.01 \\
3.99\end{array}$ & $\begin{array}{l}0.67 \\
1.50 \\
0.33 \\
0.25\end{array}$ & $\begin{array}{c}99.33 \\
101.50 \\
100.33 \\
99.15\end{array}$ & 0.940 & $\begin{array}{l}99.98 \\
\pm 0.93\end{array}$ & $\begin{array}{l}100.18 \\
\pm 0.938\end{array}$ \\
\hline $\begin{array}{c}\text { MON } \\
\text { (MONTAIR) }\end{array}$ & $\begin{array}{l}1.0 \\
1.0 \\
2.0 \\
3.0\end{array}$ & $\begin{array}{c}1.0 \\
2.0 \\
0.00 \\
0.00\end{array}$ & $\begin{array}{l}1.99 \\
3.02 \\
1.98 \\
2.98 \\
\end{array}$ & $\begin{array}{l}0.50 \\
0.67 \\
1.00 \\
0.67\end{array}$ & $\begin{array}{c}99.50 \\
100.67 \\
99.00 \\
99.33\end{array}$ & 0.730 & $\begin{array}{l}101.07 \\
\pm 01.15\end{array}$ & $\begin{array}{c}100 \\
\pm 0.725\end{array}$ \\
\hline $\begin{array}{c}\text { SIL } \\
\text { (ALISIGA) }\end{array}$ & $\begin{array}{l}10 \\
20 \\
20 \\
30\end{array}$ & $\begin{array}{c}0.5 \\
2.0 \\
1.0 \\
0.00\end{array}$ & $\begin{array}{l}10.48 \\
22.02 \\
20.98 \\
29.98\end{array}$ & $\begin{array}{l}0.19 \\
0.09 \\
0.10 \\
0.06\end{array}$ & $\begin{array}{c}99.80 \\
100.09 \\
99.90 \\
99.93\end{array}$ & 0.120 & $\begin{array}{l}99.80 \\
\pm 0.90\end{array}$ & $\begin{array}{l}100.10 \\
\pm 0.995\end{array}$ \\
\hline $\begin{array}{c}\text { TER } \\
\text { (TEBINA) }\end{array}$ & $\begin{array}{l}4.0 \\
5.0 \\
7.0 \\
8.0\end{array}$ & $\begin{array}{l}1.00 \\
1.00 \\
0.00 \\
0.00\end{array}$ & $\begin{array}{l}4.97 \\
6.01 \\
6.98 \\
7.97 \\
\end{array}$ & $\begin{array}{l}0.60 \\
0.17 \\
0.28 \\
0.38 \\
\end{array}$ & $\begin{array}{c}99.40 \\
100.17 \\
99.71 \\
99.63\end{array}$ & 0.324 & $\begin{array}{l}100.27 \\
\pm 0.58\end{array}$ & $\begin{array}{c}99.65 \\
\pm 0.315\end{array}$ \\
\hline $\begin{array}{c}\text { TRA } \\
\text { (DOLOTRAM) }\end{array}$ & $\begin{array}{l}3.0 \\
5.0 \\
7.0 \\
9.0\end{array}$ & $\begin{array}{c}1.00 \\
0.5 \\
0.5 \\
1.0\end{array}$ & $\begin{array}{l}4.02 \\
5.48 \\
7.48 \\
9.98 \\
\end{array}$ & $\begin{array}{l}0.50 \\
0.36 \\
0.27 \\
0.20\end{array}$ & $\begin{array}{c}100.50 \\
99.64 \\
99.73 \\
99.80\end{array}$ & 0.394 & $\begin{array}{c}101.20 \\
\pm 0.3558\end{array}$ & $\begin{array}{l}99.89 \\
\pm 0.401\end{array}$ \\
\hline
\end{tabular}

Table 4: Student's t-test and f-test values for pharmaceutical analysis

\begin{tabular}{|c|c|c|c|c|c|c|}
\hline $\begin{array}{c}\text { Pharmaceuticals/ } \\
\text { tablets/injection }\end{array}$ & $\begin{array}{c}\text { DAR } \\
\text { (VESIGARD) }\end{array}$ & $\begin{array}{c}\text { ESM } \\
\text { (CLOL) }\end{array}$ & $\begin{array}{c}\text { MON } \\
\text { (MONTAIR) }\end{array}$ & $\begin{array}{c}\text { SIL } \\
\text { (ALISIGA) }\end{array}$ & $\begin{array}{c}\text { TER } \\
\text { (TEBINA) }\end{array}$ & $\begin{array}{c}\text { TRA } \\
\text { (DOLOTRAM) }\end{array}$ \\
\hline $\begin{array}{c}\text { Student's } \\
\text { t-test }\end{array}$ & $\begin{array}{c}0.081 \\
(2.51)\end{array}$ & $\begin{array}{c}0.019 \\
(2.57)\end{array}$ & $\begin{array}{c}0.663 \\
(2.23)\end{array}$ & $\begin{array}{c}0.137 \\
(1.27)\end{array}$ & $\begin{array}{c}0.599 \\
(1.735)\end{array}$ & $\begin{array}{r}0.104 \\
(0.18)\end{array}$ \\
\hline \multirow{2}{*}{ f-test } & $\begin{array}{c}0.902 \\
(4.21)\end{array}$ & $\begin{array}{c}1.016 \\
(4.95)\end{array}$ & $\begin{array}{c}0.397 \\
(5.67)\end{array}$ & $\begin{array}{c}1.222 \\
(3.56)\end{array}$ & $\begin{array}{c}0.295 \\
(2.246)\end{array}$ & $(1.65)$ \\
\hline
\end{tabular}

